\title{
Company Position Analysis Using Porter's Value Chain and PEST (Political, Economic, Socio-Cultural, Technological) In PT. West Java International Airport
}

\author{
Robi Awaluddin ${ }^{1}$, Dadang Suhardi ${ }^{2}$, Dede Djuniardi ${ }^{3}$ \\ ${ }^{123}$ Management Department, Kuningan University, Indonesia \\ \{awaluddn.robi@uniku.ac.id\}
}

\begin{abstract}
The Indonesian aviation industry has very high potential, with a rapid large potential population of 240 million people and very large open market niche, recorded an average growth in aircraft passengers from 2012 to 2016, up to $4.78 \%$, based on data from The International Air Transport Association (IATA). West Java International Airport (PT BIJB) is a Regional Owned Enterprise (BUMD) formed by the West Java Provincial Government through Regional Regulation No. 22 of 2013 was established on 24 November 2014. PT BIJB is responsible for land development of West Java International Airport, as well as developing the Aero city Area which is integrated with the airport to develop the integrated surrounding economy. Based on this fact, it is necessary to conduct an internal and external potential mapping study so that PT BIJB can develop in accordance with management principles, optimize potential and minimize losses. This study used a qualitative descriptive method with in-depth interviews and focus group discussions with related parties in the internal company of PT. BIJB, internal environmental analysis is carried out using Porter's Value Chain Analysis (VCA) and in conducting external environmental analysis, the company uses the PEST (Political, Economic, Socio-cultural, Technological) analysis approach to identify opportunities or threats and their impact on the company's business activities. This research results in simultaneous and comprehensive internal and external factors, for examples the company has the basic capital to run a business in the airport sector and competing with the existing main airport of West Java Province (Husein Sastranegara) as a strength, meanwhile, the limitations of experienced human resources in the airport sector are a weakness. In terms of external factors, including the change in policies for the company's business operations as a result of the Change of the Governor of West Java is a threat and an increase in the potential for passengers and cargo due to the increasing economic capacity of the Indonesian people as an opportunity.
\end{abstract}

Keywords: Porter's Value Chain; PEST; West Java International Airport

\section{Introduction}

Indonesia's prospects in the aviation industry are increasingly being taken into account. In 2034, IATA has predicted that Indonesia will reach the 2nd largest market in the world, where in 2014 it was ranked 6th for passenger travel to, from and within the territory of Indonesia as described in Figure 1. 




Fig 1. Top Markets by Passenger Numbers 2014-2034

West Java International Airport PT is a Regional Owned Enterprise (BUMD) formed by the West Java Provincial Government through Perda No. 22 of 2013 was then established on 24 November 2014. PT BIJB is responsible for land side development as well as development and operation of West Java International Airport, as well as developing the Aero city Area which is integrated with the airport to develop the surrounding economy [1]. West Java International Airport is currently facing obstacles including the accessibility of infrastructure that has not been integrated and the level of income is low, these conditions need to be analyzed and mapped so that solutions can be immediately sought and academically, apart from having a function as planning, management science also has a function as organizing, implementing and evaluating [2].

\section{Method}

This research is a descriptive qualitative research that describes the conditions as they are. The research design is a case study at West Java International Airport located in Majalengka. Data obtained from results of focus group discussions with related divisions at West Java International Airport.

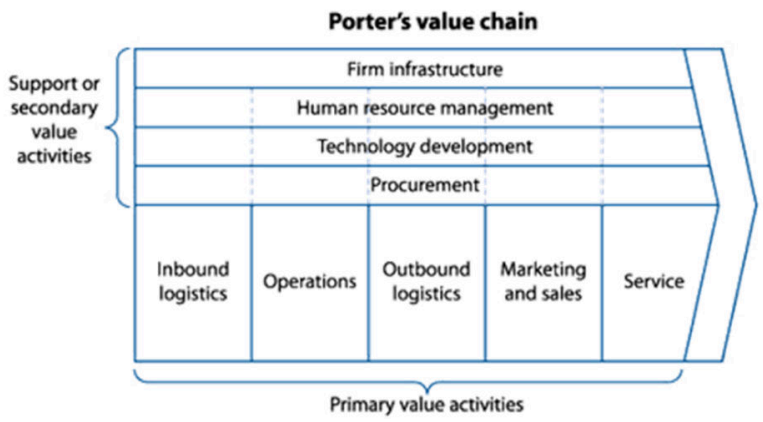

Fig 2. Porter's Value Chain 
The method used in analyzing the internal environment is Porter's Value Chain Analysis (VCA). porter's model clearly outlines six pertinent areas of the value chain; support activities which include procurement, human resources, information technology and primary activities operations \& logistics, sales and service [3]. David describes the main strengths of external analysis into five broad categories: (1) economic strength; (2) social, cultural, demographic and environmental forces; (3) political, governmental and legal forces; (4) technological strength; and (5) competitive strength [4]. The links between these forces and the organization significantly influence all products, services, markets and organizations in the world. David describes an explanation of external factors [4], namely:

a. Economic Power

Economic factors have a direct impact on the potential attractiveness of various strategies.

b. Social, Cultural, Demographic, and Environmental Strengths Social, cultural, demographic and environmental change.

c. Has a large impact on almost all products, services, markets and consumers? Small, large, profit, and non-profit organizations in all industries are surprised and challenged by the opportunities and threats that arise from changes in social, cultural, demographic, and environmental variables.

d. Political, Government and Legal Power

The government, both central and local, is the regulator, deregulator, subsidizer, employer and the main consumer of the organization. Political, governance, and legal factors, therefore, can represent major opportunities or threats to both small and large organizations.

e. The power of technology

Revolutionary technological changes and inventions have an impact on organizations. The Internet changes the very essence of opportunities and threats by changing the product life cycle, increasing distribution speed, creating new products and services, removing traditional geographic market boundaries, and changing the historical balance between product standardization and flexibility.

f. Competitive Strength

An important part of an external audit is identifying competitor companies and determining the strengths, weaknesses, capabilities, opportunities, threats, objectives and strategies. Other variables used include market share, breadth of competing products, world economy, foreign affiliation, owner's profit, price competitiveness, technological advances, population shifts, interest rates, and pollution reduction.

Evaluation of External (EFE) and Internal Factors, The Factors Evaluation (IFE) matrix can be used to determine the strategy and direction of the company's strategy. The EFE and IFE matrices are created after performing internal and external analysis. From the internal and external analysis, each factor is given the weight and value of the order of the company management. From these weights and values it is known the impact of the internal and external environment. After the number of EFE and IFE is known, then an IE-Matrix is made to see which cell the company is in and what strategic direction needs to be done [5]. 


\section{Result and Discussion}

Table 1. External Environmental Analysis

\begin{tabular}{|c|c|c|c|}
\hline No. & Factors & Impact For Business & $\mathrm{S} / \mathrm{W}$ \\
\hline \multicolumn{4}{|c|}{ Firm Infrastructure } \\
\hline 1 & $\begin{array}{l}\text { Availability of international } \\
\text { class airport infrastructure }\end{array}$ & $\begin{array}{l}\text { The company has the basic capital to } \\
\text { run a business in the airport sector } \\
\text { and compete with the existing main } \\
\text { airport in West Java Province } \\
\text { (Husein Sastranegara) }\end{array}$ & Strength \\
\hline 2 & $\begin{array}{l}\text { Does not have an airport } \\
\text { business permit }\end{array}$ & $\begin{array}{l}\text { The company must cooperate with } \\
\text { the owner of the BUBU permit }\end{array}$ & Weakness \\
\hline 3 & Capital limitations & $\begin{array}{l}\text { Limitations of company business } \\
\text { development }\end{array}$ & Weakness \\
\hline 4 & $\begin{array}{l}\text { Starting construction of } \\
\text { Kertajati aero city }\end{array}$ & $\begin{array}{l}\text { Potential passenger and goods } \\
\text { traffic, as well as potential revenue } \\
\text { from the company's subsidiary } \\
\text { managing Kertajati Aerocity }\end{array}$ & Strength \\
\hline \multicolumn{4}{|c|}{ Human Resources Management } \\
\hline 1 & $\begin{array}{l}\text { Limited experience of human } \\
\text { resources in the airport sector }\end{array}$ & \multirow{2}{*}{$\begin{array}{l}\text { Companies can lose competitiveness } \\
\text { due to less competent employees }\end{array}$} & Weakness \\
\hline 2 & $\begin{array}{l}\text { There are no career paths and } \\
\text { employee development plans } \\
\text { available }\end{array}$ & & Weakness \\
\hline \multicolumn{4}{|c|}{ Technology } \\
\hline 1 & $\begin{array}{l}\text { Application of Smart Airport } \\
1.0\end{array}$ & \multirow[b]{2}{*}{ Increase customer satisfaction } & Strength \\
\hline 2 & $\begin{array}{l}\text { use Cashless Payment System } \\
\text { at transaction points in the } \\
\text { airport environment }\end{array}$ & & Strength \\
\hline 3 & use office application systems & $\begin{array}{l}\text { Increase the effectiveness of the } \\
\text { company's business processes }\end{array}$ & Strength \\
\hline \multicolumn{4}{|c|}{ Procurement } \\
\hline 1 & $\begin{array}{l}\text { Availability of facilities and } \\
\text { cooperation to meet minimum } \\
\text { airport operating standards }\end{array}$ & $\begin{array}{l}\text { Can run the airport business and } \\
\text { business related to the airport }\end{array}$ & Strength \\
\hline 2 & $\begin{array}{l}\text { Availability of commercial } \\
\text { tenants for shopping facilities } \\
\text { for passengers and visitors }\end{array}$ & Increase customer satisfaction & Strength \\
\hline 3 & $\begin{array}{l}\text { There has not been any } \\
\text { cooperation with international } \\
\text { airlines }\end{array}$ & \multirow{2}{*}{ Lost potential income } & Weakness \\
\hline 4 & $\begin{array}{l}\text { Not yet obtained a permit as a } \\
\text { haj embarkation }\end{array}$ & & Weakness \\
\hline
\end{tabular}




\begin{tabular}{|c|c|c|c|}
\hline No. & Factors & Impact For Business & $\mathrm{S} / \mathrm{W}$ \\
\hline 5 & $\begin{array}{l}\text { There has not been any } \\
\text { cooperation with cargo } \\
\text { managers }\end{array}$ & & Weakness \\
\hline \multicolumn{4}{|c|}{ Inbound Logistics } \\
\hline 1 & $\begin{array}{l}\text { Unavailability of Cisumdawu } \\
\text { toll road access }\end{array}$ & $\begin{array}{l}\text { Losing potential passengers from the } \\
\text { catchment area of Bandung and its } \\
\text { surroundings and reducing the } \\
\text { confidence of airlines to fly from / to } \\
\text { BIJB }\end{array}$ & Weakness \\
\hline 2 & $\begin{array}{l}\text { unavailability of mode } \\
\text { integration transportation }\end{array}$ & \multirow{3}{*}{$\begin{array}{l}\text { Losing potential passengers and } \\
\text { reducing the confidence of airlines } \\
\text { to fly from / to BIJB }\end{array}$} & Weakness \\
\hline 3 & $\begin{array}{l}\text { Not yet established } \\
\text { cooperation with public } \\
\text { transportation (taxis, etc.) }\end{array}$ & & Weakness \\
\hline 4 & $\begin{array}{l}\text { Limited capacity of phase I } \\
\text { airport hotels }\end{array}$ & & Weakness \\
\hline \multicolumn{4}{|c|}{ Operations } \\
\hline 1 & $\begin{array}{l}\text { The operational reliability of } \\
\text { the airport has not yet been } \\
\text { tested because it is just } \\
\text { starting to operate }\end{array}$ & $\begin{array}{l}\text { Reduces confidence from airport } \\
\text { customers }\end{array}$ & Weakness \\
\hline \multicolumn{4}{|c|}{ Outbound Logistics } \\
\hline 1 & $\begin{array}{l}\text { The route from / to BIJB has } \\
\text { not been determined }\end{array}$ & $\begin{array}{l}\text { The delay in operating the airport } \\
\text { business has resulted in a loss of } \\
\text { potential revenue }\end{array}$ & Weakness \\
\hline \multicolumn{4}{|c|}{ Marketing \& Sales } \\
\hline 1 & $\begin{array}{l}\text { Publication of the existence of } \\
\text { airports through conventional } \\
\text { and digital media at regional } \\
\text { and national levels }\end{array}$ & \multirow{2}{*}{$\begin{array}{l}\text { Bringing passengers and the public } \\
\text { to fly / come to the airport }\end{array}$} & Strength \\
\hline 2 & $\begin{array}{l}\text { Availability of incentive } \\
\text { programs for customers and } \\
\text { the public }\end{array}$ & & Strength \\
\hline \multicolumn{4}{|c|}{ Service (Customer Service) } \\
\hline 1 & $\begin{array}{l}\text { Availability of Airport } \\
\text { Operational SOP and } \\
\text { Customer Service SOP }\end{array}$ & $\begin{array}{l}\text { Provide good service to airport } \\
\text { customers (airlines, passengers, } \\
\text { tenants) }\end{array}$ & Strength \\
\hline
\end{tabular}

External environmental analysis is carried out to obtain an overview of the external factors that influence the company's business activities. In conducting an analysis of the external environment, the company uses the PEST (Political, Economic, Socio-cultural, Technological) analysis approach to be able to identify opportunities or threats and their impact on the company's business activities which are then used to carry out a SWOT analysis. The explanation of each factor in the PT BIJB PEST analysis is described in the following table. 
Table 2. PEST Analysis

\begin{tabular}{|c|c|c|c|}
\hline No. & Factors & Impact For Business & $\mathbf{O} / \mathbf{T}$ \\
\hline \multicolumn{4}{|c|}{ Political } \\
\hline 1 & $\begin{array}{l}\text { Replacement of the Governor } \\
\text { of West Java }\end{array}$ & $\begin{array}{l}\text { Changed policies for the } \\
\text { company's business operations }\end{array}$ & Threat \\
\hline 2 & $\begin{array}{l}\text { KSO policy with PT Angkasa } \\
\text { Pura } 2 \text { for } 17 \text { years }\end{array}$ & $\begin{array}{l}\text { Lost potential revenue and } \\
\text { increased costs }\end{array}$ & Threat \\
\hline \multicolumn{4}{|c|}{ Economic } \\
\hline 1 & Increase in Indonesia's GDP & \multirow{2}{*}{$\begin{array}{l}\text { Increased potential for } \\
\text { passengers and cargo due to } \\
\text { the increasing economic } \\
\text { capacity of the Indonesian } \\
\text { people }\end{array}$} & Opportunity \\
\hline 2 & $\begin{array}{l}\text { National Industrial Growth, } \\
\text { especially in West Java and } \\
\text { its surroundings }\end{array}$ & & Opportunity \\
\hline 3 & $\begin{array}{l}\text { The growth of air } \\
\text { transportation in Indonesia }\end{array}$ & $\begin{array}{l}\text { Potential aeronautical and } \\
\text { non-aeronautical revenue for } \\
\text { the company }\end{array}$ & Opportunity \\
\hline \multicolumn{4}{|c|}{ Socio-cultural } \\
\hline 1 & $\begin{array}{l}\text { The geographical condition } \\
\text { of Indonesia which is divided } \\
\text { into thousands of islands }\end{array}$ & $\begin{array}{l}\text { Potential uses for air } \\
\text { transportation }\end{array}$ & Opportunity \\
\hline 2 & $\begin{array}{l}\text { The population of West Java, } \\
\text { which reaches } 40 \text { million }\end{array}$ & \multirow[b]{2}{*}{ Potential passengers and cargo } & Opportunity \\
\hline 3 & $\begin{array}{l}\text { Increasing the number of } \\
\text { middle-class economy class } \\
\text { and above (expenditure }>6 \\
\text { million / month) }\end{array}$ & & Opportunity \\
\hline 4 & $\begin{array}{l}\text { Application of Eco-Airport in } \\
\text { accordance with Law No. } \\
1 / 2009 \text { and SKEP / } 124 \text { / VI / } \\
2009\end{array}$ & $\begin{array}{l}\text { The potential for companies to } \\
\text { contribute in preserving the } \\
\text { surrounding environment }\end{array}$ & Opportunity \\
\hline 5 & $\begin{array}{l}\text { Limited capacity and } \\
\text { development of the main } \\
\text { airport in West Java Province } \\
\text { (Husein Sastranegara) }\end{array}$ & Potential passengers and cargo & Opportunity \\
\hline 6 & $\begin{array}{l}\text { The tourism object around } \\
\text { Ciayumajakuning has not } \\
\text { been properly developed }\end{array}$ & $\begin{array}{l}\text { Losing tourist attraction and } \\
\text { potential tourist passengers }\end{array}$ & Threat \\
\hline \multicolumn{4}{|c|}{ Technological } \\
\hline 1 & $\begin{array}{l}\text { The high cost of } \\
\text { implementing supporting } \\
\text { equipment for airport } \\
\text { operations }\end{array}$ & \multirow{2}{*}{$\begin{array}{l}\text { The potential costs that must } \\
\text { be spent in order to continue to } \\
\text { provide added value and } \\
\text { competitiveness }\end{array}$} & Threat \\
\hline 2 & $\begin{array}{l}\text { The high cost of Smart } \\
\text { Airport infrastructure (up to } \\
\text { 3.0) }\end{array}$ & & Threat \\
\hline
\end{tabular}


From each of the opportunities, threats, strengths, and weaknesses that have been identified through internal and external analysis, then an assessment is carried out to determine strategic alternatives. In order to be able to assess the opportunities and threats that come from the company's external as well as the strengths and weaknesses that come from the internal company, an assessment of the external and internal factors of the company is carried out and then plotting the values into the Internal-External (IE) Matrix as follows.

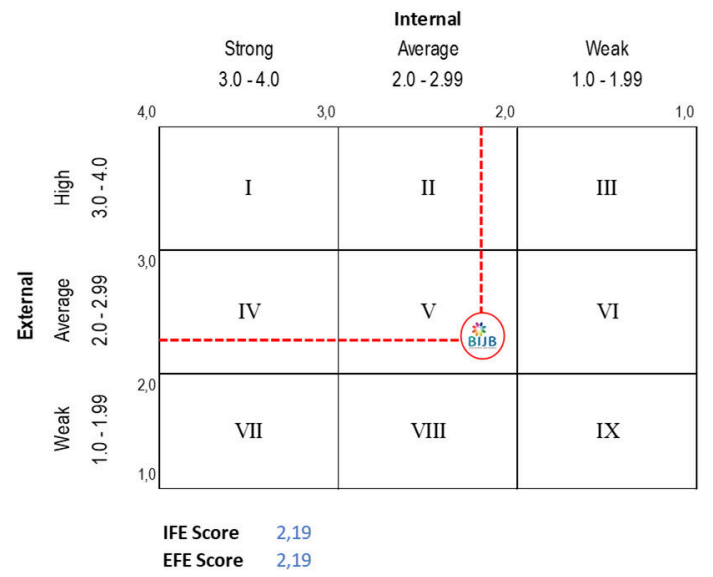

Fig 2. Internal-External (IE) Matrix

With an EFE score of 2.19 and an IFE score of 2.19, PT BIJB is in Quaternary V with alternative strategies for market penetration and product development. Alternative strategies for each quadrant are described in Table II-4 as follows.

Table 3. Alternative Strategy

\begin{tabular}{|c|c|}
\hline Quadrant & Strategy Alternatives \\
\hline \multirow[b]{2}{*}{ I, II, IV } & Grow \& Build Strategies \\
\hline & $\begin{array}{l}\text { Intensive (Market Penetration, Market Development, Product Development) } \\
\text { Integrative (Backward, Forward, and Horizontal Integration) }\end{array}$ \\
\hline \multirow[b]{2}{*}{ III, V, VII } & Hold \& Maintain Strategies \\
\hline & $\begin{array}{l}\text { Market penetration } \\
\text { Product Development }\end{array}$ \\
\hline $\begin{array}{l}\text { VI, VIII, } \\
\text { IX }\end{array}$ & Hold \& Maintain Strategies \\
\hline
\end{tabular}




\section{Conclusion}

Based on the analysis in the discussion above, it is concluded that the suitable strategy for West Java International Airport is the Hold \& Maintain Strategies which includes Market penetration and Product Development strategies.

\section{References}

[1] PT Bandarudara Internasional Jawa Barat, "Corporate Plan PT. Bandara Udara Internasional Jawa Barat 2017-2021," 2017.

[2] R. Awaluddin, "PEMETAAN INOVASI BANDARA INTERNASIONAL JAWA BARAT DENGAN BISNIS MODEL CANVAS,” J. Mantik Penusa, vol. 3, no. 3, pp. 85-91, 2019.

[3] Michael E. Porter, Competitive Advantage: Creating and sustaining superior performance. 1998.

[4] Fred R. David, Strategic Management; Concepts and Cases. Prentice Hall, 2011.

[5] D. M. I. Matrix, "Pemilihan strategi bisnis pembenihan udang vaname dengan metode internalexternal matrix," vol. 6, no. 2, pp. 62-71, 2020, doi: 10.9744/jmhot.6.2.62. 